\title{
It Started with the Stork: The Attitude Towards Sexual Health in The Netherlands, Based on Jan's Story
}

ISSN: 2640-9666

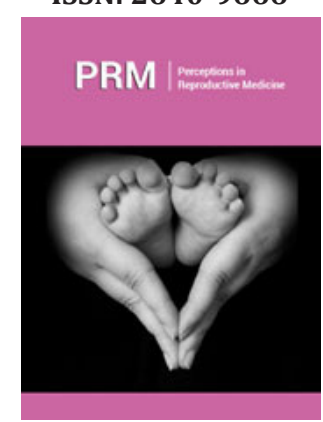

${ }^{*}$ Corresponding author: Olga Loeber, The Netherlands

Submission: 漈June 22, 2019

Published: 泚June 27, 2019

Volume 3 - Issue 3

How to cite this article: Olga Loeber. It Started with the Stork: The Attitude Towards Sexual Health in The Netherlands, Based on Jan's Story. Perception in Reproductive Medicine.3(3). PRM.000563.2019. DOI: 10.31031/PRM.2019.03.000563

Copyright@ Olga Loeber, This article is distributed under the terms of the Creative Commons Attribution 4.0 International License, which permits unrestricted use and redistribution provided that the original author and source are credited.

\section{Olga Loeber* \\ Netherlands}

\section{Introduction}

This article describes the development of views in the Netherlands on sexual health in the last century and other related information. The government, religious leaders, politicians, aid workers and socio-economic conditions all influenced existing norms. Eventually these influences seeped through to different layers of the general population. Laws and regulations were sometimes used to legalize an existing practice, sometimes as a steering method. Opinions often changed faster than these regulations. Various definitions of sexual health have been used over the years. Originally, it was mainly about preventing unwanted consequences of sex, such as unwanted pregnancy and STIs, later the current views on individual freedom, well-being and wishes were increasingly acknowledged. The WHO uses the following concept definition "Sexual health is a state of physical, emotional, mental and social well-being linked to sexuality. Sexual health is therefore more than just the absence of disease, dysfunction or weakness. Sexual health requires a positive and respectful approach to sexuality and sexual relationships, as well as the possibility of having pleasurable and safe sexual experiences, free of coercion, discrimination and violence.

To achieve and maintain sexual health, the sexual rights of all individuals must be respected, protected and realized" [1]. Leusink [2] goes one step further: "Sexual health is the ability to adjust sexually and to manage it in the light of the physical, emotional and social challenges of life. "Recently a new proposal was published by Guttmacher Lancet in which the WHO definition is further elaborated, both with regard to decision making and with regard to assistance [3]. The vision on sexual health has not always been so open and tolerant. In the period between 1925 and 1975 views on sexual relationships, the use of contraception and the sexual development of children changed fundamentally. The debate has always been very intense among all kinds of actors (government, churches, doctors and educators). The story of Jan (born in 1915) illustrates these developments.

Prologue The attitude towards sexuality, and the appropriate information provided, has changed considerably over the course of the previous 200 years. The social changes that are a possible explanation for this are described in detail in "Gevreesde vragen" (Dreaded questions) by Röling HQ [4]. At the end of the 18th century, urbanization and the emergence of a bourgeoisie occurred. Röling associates this with a general development towards more prudishness in society. Promotion of moral values such as chastity and innocence in the young is advocated. The obsessive fear of masturbation (as an explanation for all kinds of previously unexplained diseases) and again later the fear of pregnancy and venereal diseases (prostitution!) were great (Figure 1). All these dangers had to be explained to the children and with this the need for sexual education emerged. Self-control and sublimation (abstinence) until a marriage were preached. However, preferably one talked about it as little as possible. In the Catholic Church, the message was to have sexual intercourse only for the conceiving of children and the cessation of intercourse when no more children were wanted. Yet in practice, these rules were rarely adhered to. The growing wealth of parts of the population and the rise of liberalism made people more permissive in all kinds of areas. In addition, people very often did not adhere to bourgeois moral beliefs. Around 1900, more and more attention were paid to methods to limit the number of children. The (predominantly Christian) government 
was concerned about the moral deterioration at that time. In that context, a Morality Act was enacted in 1911, which engendered the following prohibitions: sale of all contraceptives (until 1969; 'the pill', introduced in 1961, could only be prescribed on medical grounds or with a family size of 12 children), abortion (illegal until 1981), homosexuality (punishable until 1971), brothels and the distribution of pornographic books (the latter prohibition continued until 1986) [5]. Despite all these measures, a large part of the population managed to limit their family size.

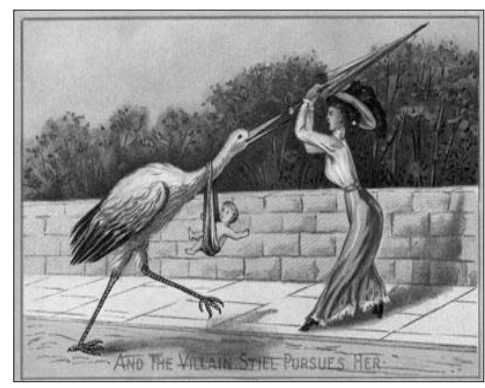

Figure 1: An early $20^{\text {th }}$ century postcard against the coercion of motherhood. ("And the villain still pursues her").

During this period, the average number of children in the Netherlands was 4.5 per family, within Catholic families 6.5 [6]. An organization that took a very different view was the Neo Malthusians Bond (NMB). The NMB was founded in 1881 by radical liberals. This organization was primarily intended to combat poverty and bring about race improvement through birth control. A statement of the NMB is: "No race improvement without a limit in numbers". This race improvement, however, did not have to do with ethnic background, but with the poorest layers of the population. Fewer children, less poverty, better health? The NMB was co-founded by Rutgers J, physician, who until 1915 was first secretary and then chairman of the NMB. From 1885 a brochure was issued: "Means to prevent large families." It described the sponge, the pessary and the vinegar flushing method.

\section{Sex Education for the Youth}

Between 1925 and 1975 there were major developments in the field of sex education for young people, sex education for marriage and birth control. In the story of Jan (born in 1915) these developments are clearly reflected. He was interviewed on October 17, 2017. "I come from a family with 4 boys. I never had any information, what I knew I heard from boys on the street. They had sisters and they sometimes had their period, then they said, "granny is over." "What is that?" "Then they have blood, then they have a bandage and my mother washes it separately and hangs it to dry separately. When we asked about it, mom said, "that doesn't concern you, those are women's issues." We knew nothing about reproduction. When my brother was born, I didn't know my mother was pregnant. When a girl was born at our neighbours, I asked where that child came from. My mother said, "it will be brought to you". "I Oh yes, how?" When I was little, she said, "through the stork" and later "I'll tell you later", but she never did. On the street they said: "what a bullshit, you have a dick and women have a slit and then you push your pecker into that slice (?), that's where kids come from." I didn't understand at all. In high school we received information about flowers and bees and pollen and pistils. One of the boys in my class asked the teacher if it was the same with people. The teacher said "No, that is different, but I am not allowed to tell you anything about that, your parents must do that". The information children received in the first half of the last century (and until the sixties!) could vary greatly. In "Gevreesde Vragen" [4] defines these dreaded questions as 1 where do the children come from? and 2 what is the father's role in this? Most parents didn't talk about this. They did not know how because of the prudish bourgeois morality of the period before. There was also a great variation in what people thought they should tell. In a conservative circle, people were "very concerned about breaching the shameful and sinful behaviour" [4]. Others promoted a more modern form of information. The most liberal example of this is the following.

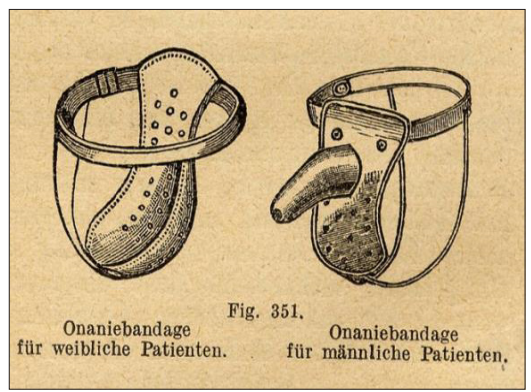

Figure 2: Anti-masturbation belt [18].

In 1926, the neurologist Annie Mulder Vande Graaf-Best caused a stir in pedagogical Netherlands. In the Tijdschrift voor Experimentele opvoedkunde (Experiential Education), she writes about the sexual education of her son. "Father, where are the seeds?" "In here JW" (pointing to the testes). "Mother, does that not tickle when father puts such a seed in?" "Yes, it does tickle a bit" "Father, do you feel that when the seed wants to get out?" "Yes boy; when you get older, the seeds sometimes come naturally. But much later you put them in your own wife [4]. This variation in approach is apparent from the content of the information booklets from that time. In 1931 Bernhard Premsela wrote in his book "Geslachtelijke voorlichting van onze kinderen" (Sex education of our children) mainly about combating all the dangers associated with sex, in particular of onanism (masturbation), which he consistently called 0. "Which are the disadvantages in the area of the nerve and soul life caused by 0. ? In short, the disadvantages can be formulated in such a way that there will be a state of imbalance. The patient is irritable, easily angry, laughs and cries easily; sleep restlessly and make an insecure, frightened impression." [5,6]. This seems to be mainly stress caused by guilt about this "dirty" behaviour and no longer the scary diseases that doctors announced half a century earlier, such as "spinal cord, brain softening and blindness" [7]; (Figure 2). On the other hand, there were also people in the past who felt that young children should be clearly informed. In 1913 Stärcke J [8] wrote: "Early information about this first question does not 
create early sexueele maturity, so it is better to do it very early than to postpone it too long. Better a year early than an hour late! You must be ahead of the information from the street! And if this timely information is neglected at home, and the child has heard something about childbirth in the street or at school, then it is still fortunate to talk about it openly at home. If, instead of providing the necessary information, the child receives a strict and unfriendly answer, then he or she will end up with no confidence (in the information from the parents). And yet many parents are so foolish". Nevertheless, he thought the same thing about masturbating as Premsela.

\section{Sex Education Prior to a Marriage Jan}

"I got married when I was 27. My girl had received a book from her father: "Het sexueele leven van den Mensch" (The sexueele life of man) by Heijermans. I also read that. A new world opened up for me. I couldn't imagine that stuff about foreplay and all that. In the film they get into bed and then go and fuck immediately. "The book that Jan mentions here (Kahn, translated and edited for the Netherlands by Heijermans is quite progressive. Heijermans finds pleasure in sexuality very important, child masturbation is called normal. Although the book is written for Roman Catholic people, he hopes that reliable means will be found in the future to regulate the number of children. In the thirties it was unusual for men to get married before the age of thirty, due to the difficulties of existence. Heijermans devotes an extensive chapter to the group of unmarried people. Theoretically, he finds abstinence the best solution. For people who suffer too much from it, he actually has no solution, except for sublimation in work, hobbies or religion. Extra-marital intercourse is risky because of the chance of pregnancy or venereal diseases, self-satisfaction drives people apart. In the Catholic Church in particular, the emphasis on the 'obligation of marriage', aimed at having children, was extreme. Catholics received a booklet from the priest with instructions for marriage. The book was written by the Balk brothers. It was titled: "Korte onderrichtingen en nuttige wenken voor gehuwden" (Brief instructions and useful hints for married people). From this booklet come the following rules for sexueele intercourse within marriage: "In the case of marriage, it is prohibited to perform any act to prevent the conception of children; one no longer commits marital acts, but marital abuse, and is guilty of the vengeful sin of unchastity against nature. And further: "Both Onanism and New Malthusianism are:

1. An act of cowardly and brutal selfishness

2. One of the most serious sins of fornication

3. One of the most serious sins against love toward one another's immortal soul

4. It murders peace of soul

5. It seduces to sacrilegious confessions and communions

6. It leads to the weakening and discarding the holy faith

7. it deletes the esteem and respect for each other

8. It often leads to marital infidelity

\section{It regularly causes nervous disease}

10. It undermines the power of the population.

Balk \& Balk [9] Within marriage, sex was an obligation to fathering (as many as possible) children, and no more than that. Another couple took another very controversial position in 1932 [4]. In their book "Wordend huwelijk" (Developing Marriage) they wrote: "While unsatisfied sexueele needs between engaged people do not allow a quiet perception of each other's spiritual qualities or peculiarities," they argued for intercourse before marriage. Contraception and abortion should therefore be permitted (more on this later) and the choice lay with the woman. The modern married woman was free to choose whether she wanted to work. The most controversial was that other partners were accepted within a marriage. The latter gave quite a stir, also within the NMB. ThJ vande Velde writes in 1926 about the pleasure of sex in the book "Volkomen huwelijk" (The ideal marriage). He writes extensively about sexueele pleasure and that a woman can be brought to orgasm by (including manual self-) stimulation of the clitoris. This book is only directed to the doctor and the husband! A woman is supposed to enter into marriage as an unwritten page and brought to sexueele blossoming by her husband: "He does not even know, the everyday husband, that the process of sexueele satisfaction for a woman is not the same as for him; he has no idea that her feelings must first be gradually aroused in a careful manner" [10]. He hardly writes about masturbation. These are just a few examples of the many information books. What is striking are the large differences in moral and factual attitude towards sexuality. The public debate between more liberal and more conservative, between religious and non-religious people ran high. Pedagogues and moralists tried to get politicians to take often contrary measures. Homosexuality, abortion, pornography and sexual violence are not discussed anywhere. Some of these information books were reprinted for years and were very popular. The NVSH was founded in 1946 (the Dutch Association for sexueele Reform). The NVSH possessed a whole building in Rotterdam (dr. J. Rutgershuis, opened in 1935 as a Consultation Office for Marriage and sexueele Life, first of the NMB, later the NVSH) Jan: "In 1947 I started working for the NVSH for eight years as a volunteer to manage the library, because I supported their ideas. We purchased books for the library. Information books, also in form of a novel, such as "L'histoire d'O" from de Sade and "Lady's Chatterley's lover". In our time it was very strange if you walked in your bare ass and put flowers in your pubic hair, as described in that book. People still had pubic hair, sometimes very long. You could sometimes make braids in it. Those books were loaned for a dime a week.

In addition to information about sexuality and the myths surrounding it, information was also given about childcare and upbringing in class. As a magazine we first had 'Wise Parenthood' and later 'Sextant'. I never actually read it, because it was all the same, but I did read the letters sent to the editor and the We Want to Know section." Jan explains how things went later with the information to his children: "My wife has given extensive information to our children. Yet at that time (around 1960) there 
was still a lot of ignorance and my daughter came home crying once, because the girls in her class had scolded her because she had claimed that children were not brought by the stork". The information the NVSH propagated was extremely progressive in the 50s and 60s. In the Sextant were articles like: "Is the woman still a pleasure object?" Or "stimulation-matter", about the woman's right to excitement and orgasm. They dealt with topics such as female eroticism, homosexuality, abortion and premarital sex. In 1954 the episcopal mandate forbade Roman Catholics to become members of the NVSH [11]. Catholics and Reformed people were forbidden to use contraception. This was contrary to the law of nature. Becoming a member of the NVSH was therefore out of the question. The church disapproved of the NVSH and talked about the "horrible, degrading NVSH, which they thought should actually be called NVSL: Dutch Association of the Bad Living."

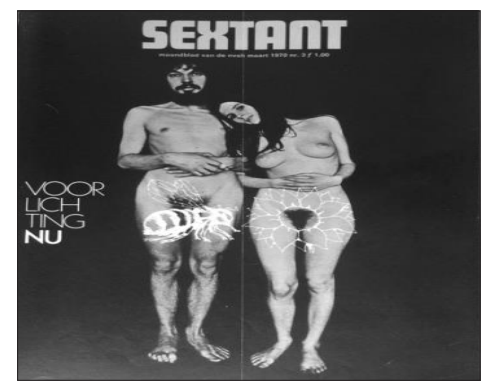

Figure 3: Front page sextant March 1970, nr 3. (photo by author; with permission NVSH).

\section{Birth Control}

Jan: I supported the ideas of the NVSH. First that you can enjoy sexuality and further that there should not be too many children. My wife sat at the reception to sell the "means", condoms and such. People did not see the doctor for birth control, but only if there were problems for instance because they were afraid of contracting a venereal disease and very often because they did not get pregnant. Then it turned out that lovemaking in bed meant only sleeping there together" as spoons doctor, wonderful". but only that. People were sometimes married for years without having seen each other naked. The nurses provided information about the different methods of birth control: condoms, diaphragms, periodic abstinence according to Ogino Knauss. Unwanted pregnancy, abortion and sterilization were never discussed, even if you had enough children. This was progress compared to his own 'education' in the field of birth control. Jan: "There was a book in our house with pictures of condoms and sponges and round things with tubes attached, which baffled us. We immediately put it away again, because when our mother found out, hell would be raised. We would be grounded. They had a large glass cylinder with hoses attached to it in the cupboard. Nothing was explained about this. That didn't always go according to plan, because I had another brother when I was eight years old (Figure 4). I was sent to Berlin during the war for the Arbeitseinsatz (forced labour) and was given two weeks off to go to the Netherlands to get married. You could easily get condoms (Überzieher) in Berlin, so I brought a number of them. You could also buy washable condoms later in the Netherlands, but only under the counter and they were scarce. So, when the war was over, I brought a supply and when they ran out, I was very reluctant to buy them in such a store, and then a friend told me that you could buy it at a building in Rotterdam, at the Birth control department. You bought the condoms from the concierge. I have done that for years. I asked the concierge what they were doing there. He told me that they also provided sex education by doctors, because there was a lot of ignorance, and nonsense was often told. I asked my wife if she wanted to go there. "Not me," she said, "don't you know enough?" I said, "Well, wouldn't there be more?" "No, Jan," she said, "that's all pornography." Here ends Jan's story.

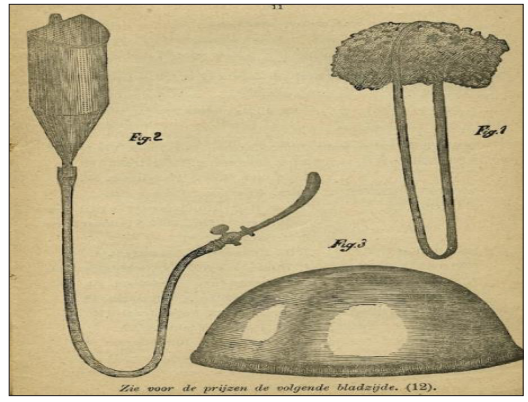

Figure 4: Brochure methods to prevent large families.

\section{Epilogue}

"The pill" was introduced in the Netherlands in 1961 and as a result the attitude towards sexueele health in the Netherlands changed fundamentally. The sexueele revolution took place at the same time. Attention was paid to the (sexueele) rights and wishes of the woman, to abortion, to rape within the marriage and to gay emancipation. The progressive, positive attitude that was accepted by a large part of the population in this flower-power era has long existed. For example, until the 1980s, a delivery could be shown on television without any problems (in "How does the Netherlands give birth") as Ria Bremer said, while that would now encounter a lot of resistance. The sociologist Cas Wouters describes, on the basis of the subsequent editions of etiquette books ("How to behave?"), the change in codes of conduct and ideal behaviour between men and women. In the 1930s there was a 'harmonious inequality' between man and woman, with the man leading and the woman following. This was followed in the 60's by the second sexueele revolution and emancipation of women, resulting in informalization and equality of the relationships. The changes in the male-female relationship had a tremendous impact on the sexueele relationship. Wouters [12] describes the change in the 'lust balance' due to the influence of the female lust experience. This led to changes in the sense of the sexualization of love and the eroticization of sex. Incidentally, the informalization seems to be declining since the late 1970s. Shortly before the introduction of the pill, birth control was really a taboo topic, except in very progressive circles. When two articles on this subject appeared in the Dutch Journal of Medicine (NTvG) in 1949 $[13,14]$, written by two female doctors, it caused 180 doctors to write that their feelings were seriously hurt. This again resulted in nothing being published about contraception in the NTvG during the following 15 years [15]. With the introduction of the pill, birth 
control came for the first time almost completely in medical hands. Contraceptive methods that did not require medical supervision, such as a condom, pessary and natural birth control, were put in a bad light as "not reliable and old-fashioned". The dr. J. Rutgers Foundation was established in 1969 as a medical organization that prescribed birth control and also dealt with other aspects of sexual health. The NVSH continued to exist as a progressive think tank [16]. In 1975 the pill was by no means prescribed by all general practitioners, certainly not to adolescents and unmarried women. People were still worried about possible medical side effects. The women had to come every six months for a thorough physical and gynecological examination (personal experience). The arrival of the pill has brought a large number of advantages, but also disadvantages, such as being constantly available through protection against unwanted pregnancy (but not against the risk of venereal disease) and the medicalization of birth control $[17,18]$. The medicalization of reproductive health was reinforced by the arrival of the HIV epidemic. The emphasis on all possible negative consequences of sex has until recently been one of the problems with sexuality education.

Overlooking this short retrospect, a number of things stand out: The public debate about sexuality has always been fierce and varies from discussing all kinds of risks associated with sex to periods in which sexuality is perceived as a positive part of life. The government is trying to steer sexual health through all sorts of measures and laws for moral policy reasons. It takes a long time before the relevant legislation is adapted to changing views. The influence of the church is clearly visible in views on sexuality and family size, next to the general moral views of the non-religious population on how to behave. The general population is hardly concerned with what the government wants and seeks its own solutions. Doctors appropriated the birth control system almost completely for the first time after 1960 and methods that lie outside their field are usually characterized as old-fashioned and not reliable. Perhaps superfluous: the views of a large part of the population change much more slowly than those of a small liberal vanguard, as can be seen from the stubborn tradition of the stork.

\section{References}

1. World Health Organization (2006) Defining sexual health. Report of a technical consultation on sexual health. WHO, Geneva, Switzerland, pp. 28-31.
2. Leusink P (2017) Vision on sexual health: towards a new definition of sexual health. Journal of Sexology 41: 122-126.

3. Starrs AM, Ezeh AC, Barker G, Basu A, Bertrand JT, et al. (2018) Accelerate progress-sexual and reproductive health and rights for all: report of the Guttmacher-Lancet Commission. The Lancet Journal 391(10140): 26422692.

4. Rölink HQ (1994) Dreaded questions: History of sex education he Netherlands. University Press, Amsterdam, Netherlands.

5. Premsela B (1931) Sex education of our children. Mulder \& Co Regout, ERH, Amsterdam, Netherlands.

6. Somers A, Van Poppel F (2003) The decay of marital chastity. The influence of the priests on the birth control among Catholics in the Netherlands in the period, 1935-1970.

7. La Mert S (1841) Self-preservation: a popular inquiry into the concealed causes of those obscure and neglected disorders of the generative system originating in certain solitary habits, and youthful excesses and terminating in nervous debility, impotence, sterility, insanity and consumption. Manchester, United kingdom.

8. Stärcke J (1913) The sexual education of our youth. Society for good and cheap reading. Amsterdam, Netherlands.

9. Balk JWB, Balk AWA (1910) Short instructions and useful tips for married couples. Publ Ros.

10. Vande VTHH (1923) The perfect marriage (The ideal marriage). Leidsche Uitgeversmaatschappij, Leiden, Netherlands.

11.Episcopal Mandement (1954) The Catholic in public life today. In: Reverse effect of the mandement (1954-1960).

12. Wouters C (1987) Developments in the Behavioral Codes between the Sexes: The formalisation of informalisation in the Netherlands, 1930-85. Theory, Culture \& Society 4: 405-427.

13. Scheltema JA (1949) Birth control in the Netherlands and some other European countries. Dutch Journal of Medicine 93: 4263-4269.

14. Wijnberg R (1949) Contraceptives against pregnancy. Dutch Journal of Medicine 93: 4242-4245.

15. Treffers PE (2006) Abortion in the Netherlands in the $20^{\text {th }}$ century: from silence to revolutionary change. Dutch Journal of Medicine 150: 567 573.

16. Brummel D (2005) After the peak. De Nieuwe Sekstant.

17. Kahn F (1937) The sexual life of man. Amsterdam, Netherlands.

18. Moll A (1921) Handbook of sexual sciences. Publisher of FC Bird, Leipzig, Germany.

For possible submissions Click below: 